\title{
Aikuiskoulutuksen tutkimusverkostojen toimintaa ESREA:ssa
}

ESREA:n (European Society for Research on the Education of Adults) kahdentoista eri tutkijaverkoston toiminta on kaiken aikaa vilkastunut. Osallistuin keväällä kahden eri verkoston seminaareihin, joista seuraavassa kerron ajankohtaisia kuulumisia. Kerron myös lyhyesti kuulumiset aikuiskouluttajien täydennyskoulutukseen liittyvästä konferenssista Leedsissä.

\section{Työmarkkinapolitiikan ja koulutuksen yhteydet}

ESREA:n tutkimusverkosto "Adult education and labourmarket" järjesti kolmannen seminaarinsa Leedsissä viime maaliskuussa. Verkoston koordinaattorina toimii professori Henning Sanning Olesen Roskilden yliopistosta. Tapaamiseen osallistui tutkijoita Hollannista, Englannista, Tanskasta, Kanadasta ja yksi Suomesta. Verkoston tutkimusteemoina ovat aikaisemmin olleet pääasiassa työmarkkinapolitiikan ja koulutuksen väliset yhteydet sekä ammattiyhdistysliikkeen ja koulutuksen väliset suhteet, joiden teemojen ympärille on muodostunut tiivistä tutkimusyhteistyötä mm. Leedsin ja Roskilden yliopistojen välille. Näistä aihepiireistä oli ko. yliopistojen tutkijoiden esitykset myös tässäkin seminaarissa.

Tutkimusteemoina verkoston seminaareissa ovat olleet aikaisemmin myös kvalifikaatio- ja professionalismitutkimus. Lähestymistavat ovat olleet voittopuolisesti kasvatussosiologisia, kuten monessa esityksessä tälläkin kerralla. Tutkimusintressit ovat kuitenkin siirtymässä yhteiskuntapoliittiselta metatasolta myös organisaatiotasolle, joka näkyy uusina tutkimusteemoina, kuten oppimisen organisoiminen yrityksissä, oppivan organisaation käsitteen tarkastelu sekä aikuisopiskeluun ja urakehitykseen liittyvät orientaatiotutkimukset. Erityisen ilahduttavaa oli aikaisemmin sosiologisesti suuntautuneiden tutkijoiden kiinnostuksen viriäminen myös organisaatiotutkimusta ja oppimisen tutkimusta integroivaan lähestymistapaan.

\section{Työelämän ja oppimisen yhteyksien tutkimustarve}

Seminaarissa näkyi selvästi työelämän ja oppimisen yhteyksiä käsittelevän monitieteisen tutkimuksen tarve, ja myös erilaisten oppimista koskevien teoreettisten lähestymistapojen tarve. Tämä koskee myös Suomessa tehtävää tutkimusta. Olisi kohtalokasta, jos näin tärkeä tutkimusalue rajattaisiin vain yhden koulukunnan ja lähestymistavan "omaisuudeksi".

Verkostoseminaarin esitykset julkaistaan proceedings-kirjana vielä kuluvan vuoden puolella. Sitä on saatavilla Roskilden yliopiston aikuiskasvatuksen yksiköstä. Tässä seuraavaksi lyhyesti esimerkkeinä Roskilden tutkijoiden Anders Vindin ja Henning Sanning Olesenin sekä kanadalaisen Leif Hommenin esitysten teemat.

\section{Työpaikan oppimisprosesseista ja organisaatioympäristöistä}

Anders Vind esitteli viime vuonna Tanskassa alkanutta KOLORIT-projektia, jossa paneudutaan oppimisprosesseihin työpaikalla sekä työntekijän kehitystä ja oppimista tukeviin organisaatioympäristöihin. Projektin tutkimusintressit ovat samansuuntaisia viime vuonna Tampereen yliopistossa käynnistyneen 
tutkimusprojektimme kanssa, joka käsittelee työn, organisaation ja oppimisen suhteita (projekti kuuluu Suomen Akatemian koulutuksen vaikuttavuuden tutkimusohjelmaan; ks. Aikuiskasvatus 2/95).

\section{Kvalifikaatiot ja henkilökohtainen identiteetti}

Professori Henning Sanning Olesen esitteli kvalifikaatiotutkimusryhmänsä pohdintoja tulevaisuuden kvalifikaatioista, tapausesimerkkinä toimistotyö. Ryhmän tutkimuksen keskeisenä teesinä on henkilökohtaisen identiteetin muodostuminen sosiaalisen elämän kvalifikaatioista, persoonallisista sekä työelämäkvalifikaatioista, jotka jäsentyvät kolmelle tasolle: perus-, täydentävät ja erityiskvalifikaatiot.

Leif Hommen käsittelee hyvin kiinnostavalla tavalla PKT-yritysten mikrokontekstissa tapahtuvan "institutionaalisen oppimisen" suhdetta makrotason taloustieteellisiin tulkintoihin PKT-yritysten kehityslinjoista.

Tämän networkin kahdesta aikaisemmasta seminaarista on myös julkaistu kirjat, joita saanee ESREAn kautta. Julkaisujen nimikkeet ovat: "Adult Education and Labour Market 1 (1994); 11 (1996).

\section{Leedsissä painottuu työelämän jatkokoulutus}

Seminaarin isäntäyksikössä eli Leedsin yliopistossa aikuiskasvatus ja kasvatustiede ovat vahvasti painottuneet aikuisten ammatilliseen täydennyskoulutukseen. Sitä kuvaavat jo laitosten nimikkeet ja laajuudet: suurin yksikkö on Department of Adult Continuing Education, muita osastoja ovat Department of Continuing Professional Education (em. yksiköt yhdistyvät lähitulevaisuudessa) sekä School of Education. (Myös muissa tiedekunnissa on omia täydennyskoulutusyksiköitä, kuten esimerkiksi lääketieteellisessä tiedekunnassa.) Opiskelijat ovat suurelta osin osa-aikaopiskelijoita työelämästä, ja opiskeluun liittyy myös työelämään kytkettyjä jaksoja. Aikuiskoulutuksen osastolla on vahvat siteet Leedsin yliopiston työelämän suhteita tutkivaan yksikköön: Centre for Industrial Policy and Performance sekä työelämän etujärjestöihin ja ammatillisiin järjestöihin.

Minulla oli mahdollisuus osallistua välittömästi ESREA-seminaarin jatkeeksi Leedsissä pidettyyn kansalliseen täydennyskoulutusta käsittelevään konferenssiin, jonka järjesti täydennyskoulutus- ja aikuiskoulutusyksiköiden kansallinen järjestö UACE yhdessä Leedsin yliopiston kanssa. Konferenssiin osallistui vajaa kaksisataa aikuiskouluttajaa, ja sen tavoitteena oli vahvistaa heidän ammatillista kehitystään ja kompetenssejaan. Yleisluentojen ohessa oli runsaasti työpajoja, joissa esiteltiin sekä tutkimusten että käytännön tapausesimerkkien valossa ammatillisen kehittämisen "työvälineitä".

Erityisesti esillä olivat mentoroivan ja konsultoivan työotteen kehittäminen aikuiskouluttajan työssä, kompetenssipohjaiset ja työelämään kytketyt koulutusohjelmat, yliopistojen uusi rooli ammatillisen aikuiskoulutuksen kehittämisessä sekä tietysti koulutusyksiköiden rahoitusongelmat ja asiakaskilpailu. Kansallisesti tärkeä osa-alue, jonka kehittämistä paljon pohdittiin, on ns. yhdyskunta-kasvattajien (community adult educators) rooli ja heidän vetämänsä yhdyskuntakehitysprojektit. Niiden taustalla on sekä järjestöjen, yritysten että jonkin verran julkista rahoitusta.

\section{Britanniassa huolena kapean ammattiosaamisen suosiminen}

Erityisen kiihkeää debattia käytiin Britanniassa yhä yleistyvämmästä ilmiöstä eli kansallisten komiteoiden laatimista ammatillisista kvalifikaatioluokituksista, joiden avulla voi en aloilla hankkia eritasoisia "kvalifikaatiotodistuksia". Monet yritykset käyttävät näitä sertifikaattijärjestelmiä hyväkseen työntekijöitä hankkiessaan. 
Kritiikki on kohdistunut voimakkaasti siihen, että luokitukset (National Vocational Qualifications) suosivat teoreettisen tiedon ja yleisten kvalifikaatioiden kustannuksella käytännön taitoja (ja usein hyvin kapeita). Tämä on koettu huolestuttavaksi myös siksi, että järjestelmä on laajenemassa korkean asteen ammatillisille aloille, josta syystä etenkin yliopistojen edustajien kritiikki oli purevaa. Hämmennystä on lisännyt se, että eräät yliopistot ovat ryhtyneet muokkaamaan omia koulutusohjelmiaan siten, että niissä jo ennakoidaan kunkin alan ammatillisia kansallisia kvalifikaatiovaatimuksia, jotta ko. yliopistosta valmistuvat varmasti pärjäävät ko. "mittauksissa".

Kritiikkiin on pyritty vastaamaan laajentamalla kompetenssialueita teoreettiseen ja yleisten kvalifikaatioiden suuntaan uutta luokitusjärjestelmää kehittelemällä.

Osallistujat ko. konferenssissa olivat minua lukuunottamatta Brittein saarilta, vaikka siitä oli $\mathrm{mm}$. kansainvälisissä verkoissa ilmoitettu laajasti. Kokemani pohjalta voisi suositella myös suomalaisille aikuisja täydennyskouluttajille osallistumista UACE:n konferensseihin yleisemminkin, siksi kiinnostavia ja laadukkaita eräät työpajat olivat.

\section{Barry Haken kritiikin suunta oli toinen: yliopistot}

Toisen ESREA:n tutkimusverkoston seminaari oli "Continuing Professional Education" networkin järjestämä Leidenissä Hollannissa toukokuussa. Verkoston tapaaminen oli jo toinen tänä vuonna, ja kolmaskin järjestettiin marraskuussa Portugalissa. Julkaisuja näistä seminaareista ei toistaiseksi ole tullut. Tähän tapaamiseen osallistui tutkijoita ja aikuiskouluttajia Itävallasta, Englannista, Portugalista, Saksasta, Hollannista, Tanskasta, Ruotsista ja jälleen vain yksi Suomesta. Verkoston koordinaattorina toimii professori Geoff Chivers Sheffieldin yliopistosta.

Seminaarissa kuultiin katsaus EU:n ammatillisen aikuiskoulutuksen linjauksista sekä maakohtaiset esitykset ammatillisen aikuiskoulutuksen politiikasta Saksassa, Itävallassa, Hollannissa ja Portugalissa. Vertailussa vaikeutti koulutusta organisoivien tahojen kirjavuus sekä varsin erilaiset tilastointitavat ja niiden tuoreus.

Professori Barry Hake kritisoi voimakkaasti monien hollantilaisten yliopistojen elitististä asennetta ammatilliseen täydennyskoulutukseen. Hänen mielestään tämä alue on toistaiseksi hoidettu varsin puutteellisesti vastoin virallisissa visioissa ja juhlapuheissa esitettyjä "lifelong learning" ja "learning society" fraaseja. Hän katsoi, että ammatillinen täydennyskoulutus olisi nostettava tärkeimmäksi keskeiseksi missioksi yliopistoissa ja että professionaalisten organisaatioiden ja yliopistojen välistä yhteistyötä on voimakkaasti tuettava.

Myös tässä verkostoseminaarissa oli esillä kompetenssitutkimus sekä oppimisen organisoimista työpaikalla käsittelevää tutkimusta. Geoff Chivers ja Graham Cheetham esittelivät kehittelemäänsä professionaalisen kompetenssin hofistista mallia, josta sittemmin on ilmestynyt artikkeli lehdessä Joumal of European Industrial Training (20/5/96). Nijmegenin yliopistossa professori van der Krogtin vetämä tutkimusryhmä kehittelee oppimisverkostoteoriaa ja on soveltanut sitä mm. työpaikkasidoksisten oppimisprojektien ja oppimisilmapiiritutkimuksiin.

\section{ESREA vaikuttajan keskeinen rooli EU:ssa?}

Verkoston vetäjä, professori Chivers pohti myös jaetussa tutkimusagendassaan, minkä tyyppisiä asiakokonaisuuksia olisi sisällytettävä EU:n jäsenvaltioiden ammatillisen aikuiskoulutuksen kenttää koskevaan katsaukseen ja mitkä olisivat näin ollen myös tärkeitä tutkimusteemoja. Hän kaipasi kouluttajien kehitysprosesseja koskevaa tutkimusta, työssäoppimisen tutkimusta, ammatillisen aikuiskoulutuksen arviointia, arviointitutkimusta erilaisten oppimisen lähestymistapojen tehokkuudesta sekä kouluttajakoulutuksen vaikuttavuudesta, tietoa siitä, miten uusi teknologia vaikuttaa aikuiskouluttajien 
rooliin ja mitä se tarjoaa kouluttajien kehitysstrategioille, kuinka globaali talous muuttaa kouluttajien ja HRD-eksperttien roolia, jne. Hän myöskin kaipasi kasvatustieteilijöiltä parempaa perehtyneisyyttä alakohtaisiin täydennyskoulutusjulkaisuihin esimerkkeinä tekniikan alan ja lääketieteen alan julkaisut.

Professori Chivers korosti myös voimakkaasti ESREA:n näkyvämpää ja aktiivisempaa roolia EU:n erilaisten koulutus- ja tutkimusrahoituskanavien tunnetuksi tekemisessä ja hyödyntämisessä. Tämä konkretisoitui jo tässä seminaarissa, kun kahden tai kolmen hengen tutkijaryhmät saivat tehtäväkseen seuraavaan tapaamiseen mennessä selvittää yksityiskohtaisesti yhdeksän eri rahoituslähteen hyödyntämismahdollisuudet erityisesti ammatillisen aikuiskoulutuksen tutkimuksessa ja kehittämisessä.

\section{Suomalaiset aktiivisemmin mukaan!}

Summa summarum: olen vakuuttunut siitä, että suomalaisten aikuiskouluttajien ja alan tutkijoiden on syytä huomattavasti lisätä aktiivisuuttaan ESREA:n alaisissa tutkijaverkostoissa, joiden tapaamiset organisoituvat nopeasti ja ovat kustannuksiltaan kohtuullisia, ja mikä tärkeintä, tuottavat tutkijakontakteja, joista voi lähteä melko nopeastikin yhteisen tutkimustoiminnan suunnittelu liikkeelle. Ennen kaikkea ESREA on tulevaisuudessa todennäköisesti se väylä, minkä kautta EU:n aikuiskoulutukselle ja -kasvatukselle suuntaama rahoitus suureksi osaksi kanavoituu.

\section{Annikki Järvinen}

